\title{
ANALISIS YURIDIS DAMPAK E-COMMERCE TERHADAP POTENSI KEHILANGAN PAJAK NEGARA INDONESIA
}

\author{
Rachmasariningrum \\ Program Studi Magister Kenotariatan Universitas Surabaya, Indonesia \\ Email: nining1110@gmail.com
}

\begin{abstract}
ABSTRAK
Penelitian ini dilakukan dengan tujuannuntuk mengetahui transaksi e-Commerce dan regulasi khusus terkait pajak negara dan upaya pemerintah indonesia dalam mengatasi risiko kehilangan pajak akibat penggunaan transaksi online (e-Commerce) serta untuk mengetahui keterkaitan suatu bisnis jika tidak diimbangi dengan peraturan yang berlaku khusus akan berdampak kurang baik terhadap bidang lain yang juga merupakan sektor utama dalam perwujudan pembangunan. Penulisan ini menggunakan metode yuridis normatif dengan pendekatan kepustakaan yang berpedoman pada bahan hukum primer, sekunder dan tersier yang diolah dan diuraikan dalam bentuk deskriptif kualitatif serta dianalisa dengan menggunakan penalaran deduktif. Hasil penelitian ini menunjukkan bahwa untuk memaksimalkan penerimaan pajak dari transaksi online, maka perlu adanya regulasi yang secara khusus diterapkan pada transaksi online dan sistem pengawasan yang solid agar penerimaan pajak dari transaksi online dapat terkumpul secara maksimal.
\end{abstract}

Kata Kunci: E-Commerce; Pajak.

\begin{abstract}
The research was conducted with the aim of seeing e-Commerce transactions and specific regulations related to state taxes and the efforts of the government in addressing the risk of tax loss due to the use of online transactions (e-Commerce) and to find out the linkages of a business which are not balanced with regulations that apply specifically will have a negative impact on other fields which are also the main sectors in the realization of development. This writing uses a normative juridical method with a literature approach that is guided by primary, secondary and tertiary legal materials which are processed and described in descriptive qualitative form and analyzed using deductive reasoning. The results of this study indicate that for tax revenue from online transactions, it is necessary to have regulations specifically applied to online transactions and a solid monitoring system so that tax revenues from e-Commerce transactions can be collected optimally.
\end{abstract}

Keywords: E-Commerce; Taxation.

\section{PENDAHULUAN}

Lalu lintas teknologi yang berkembang di era revolusi industri 4.0 dan sosial 5.0 memberikan dampak yang signifikan dalam pertumbuhan ekonomi duniakhususnyadiIndonesia(Hendarsyah, 2019). Dampak tersebut terlihat dari munculnya berbagai market place serta bisnis-bisnis online lainnya seperti Shopee, Lazada, JD.ID. Tokopedia, Bukalapak dan lain-lain. Tingginya pertumbuhan pelaku bisnis secara online dilatarbelakangi dengan konsumerisme masyarakat yang relatif tinggi, sehingga berbagai inovasi dibidang perdagangan/transaksi online terus mengalami peningkatan dan pembaharuan demi memberikan kemudahan bagi para konsumen dalam memenuhi kebutuhannya. Kegiatan perdagangan/transaksi tersebut selanjutnya dikenal dengan e-Commerce.

Pesatnya pertumbuhan e-Commerce telah mencapai 500 persen selama 4 (empat) tahun terakhir berdasarkan hasil riset Google dan laporan e-ConomySEA 2018 yang menampilkan data transaksi e-Commerce di Indonesia hingga menembus angka US\$ 27 miliar atau setara dengan Rp 391 triliun (Rahayu 2019). Tingginya 
tingkat pertumbuhan e-Commerce juga disampaikan oleh Septriana Tangkary selaku Direktur Pemberdayaan Informatika Kominfo yang memaparkan nilai e-Commerce ditahun 2018 menembus angka 78 persen, hal tersebut menempatkan Indonesia sebagai peringkatpertamadi dunia(Zuraya, 2019). Dan berdasarkan data dari Bank Indonesia, pada Januari 2019, transaksi online telah mencapai Rp. 8,204 $\mathrm{T}$ dan mengalami peningkatan sebesar 135,8 \% dibandingkan tahun 2018 (Nugraha, 2019). Nilai transaksi online sendiri pada tahun-tahun sebelumnya mencapai 200 $\mathrm{T}$ per tahun dengan potensi pajak PPN dan PPH sekitar 10-15 triliun per tahun.

Pesatnya pendapatan ekonomi dibidang e-Commerce seharusnya memberikan dampak yang signifikan pada pendapatan pajak negara. Namun Ironisnya proyeksi pajak dalam jumlah besar tersebut belum bisa terkumpul secara maksimal. Direktur Eksekutif Center for Indonesia Taxation Analysis (CITA), Yustinus Prastowo mengatakan negara bisa kehilangan potensi pajak hingga $10 \%$ dari transaksi e-Commerce apabila Ditjen Pajak tidak mampu mengumpulkan pajak pada sektor ini (Leonardo \& Tjen, 2020).

Problematika perolehan pajak Negara yang kurang maksimal didasarkan pada minimnya regulasi mengenai perpajakan e-Commerce (Valentino \& Wairocana, 2019). Dalam Undang-Undang Nomor 28 Tahun 2007 tentang Ketentuan Umum dan Tata Cara Perpajakan (UU Perpajakan) substansinya belum mengakomodir perpajakan di sektor transaksi online. Namun, di sisi lain terdapat Peraturan Pemerintah (PP) No. 80/2019 tentang Perdagangan Melalui Sistem Elektronik. Adanya PP tersebut dianggap belum dapat mengatasi problematika penarikan pajak e-Commerce bagi pelaku bisnis online $\mathrm{di}$ Indonesia. selanjutnya ketentuan pasal 2 ayat (5) Undang-Undang Pajak Penghasilan yang menjelaskan mengenai Bentuk Usaha Tetap (BUT) yang mengharuskan adanya keberadaan fisik tempat usaha terkait penyelenggaraan transaksi elektronik. Namun, dalam substansi pasal tersebut tidak dapat mengakomodir dan menjangkau BUT perusahaan e-Commerce di luar Indonesia, yang notabene pendiri/pemilik saham serta target pasar konsumen ada di Indonesia (Vidyana \& Amachi, 2014). Artinya, ketentuan pasal tersebut juga belum dapat mengakomodir masalah pajak e-Commerce secara keseluhuan, sehingga untuk pelaku e-Commerce demikian, tidak dapat dilakukan penarikan pajak sebagaimana mestinya.

Sedangkan Regulasi mengenai perlakuan perpajakan e-Commerce pernah dikeluarkan dalammbentuk Peraturan Menteri Keuangan (PMK) di tahun 2018 yang selanjutnya akan diberlakukan pada tanggal 1 April 2019. Namun, sebelum regulasi PMK-210/PMK.010/ 2018 diimplementasikan Menteri Keuangan menarik kembali aturan tersebut, sehingga batal diberlakukan (Leonardo \& Tjen, 2020). Dicabutnya regulasi tersebut disebabkan beberapa kekurangan sebagaimana hasil studi lapangan Asosiasi e-Commerce Indonesia yaitu (i) ditakutkan akan menghambat pertumbuhan UMKM di Indonesia; (ii) dapat membunuh pengusaha mikro akibat kewajiban pembuatan NPWP baik untuk pengusaha lama maupun pemula; (iii) minimnya aturan untuk pengusaha yang menggunakan media sosial untuk berdagang, sehingga banyak pengusaha e-Commerce yang pindah haluan dan mengakibatkan jumlah pengusaha e-Commerce berkurang dan bahkan bisa tutup (Farras, 2019).

Berdasarkan uraian diatas, pengenakan pajak e-Commerce yang tidak dapat dilakukan secara serta merta dan maksimal kepada semua bidang e-Commerce yang berseluncur dan beraktivitas di Indonesia sebab regulasi yang kurang memadai dalam sektor ini. Dari permasalahan tersebut pemerintah perlu mengeluarkan aturan hukum secara khusus serta dapat melakukan studi komparasi di beberapa negara maju yang telah sukses melaksanakan kebijakan 
perpajakane-Commerce. Bentuk suksesnya implementasi pajak e-Commerce dinegara lain ditandai dengan adanya harmonisasi antara regulasi dan teknologi. Dari sini, Pemerintah dapat mengeluarkan kebijakan aturan baru dengan dibarengi adanya teknologi sebagai control laju adanya aktivitas transaksi online dengan tujuan agar roda perekonomian dapat berjalan lancar dengan diimbangi pemasukan pajak guna mensejahterahkan dan memakmurkan rakyat Indonesia sebagaimana amanat dari Undang-Undang Dasar 1945.

Penelitian ini bertujuan untuk mengetahui aspek hukum yang mengatur pajak e-Commerce di Indonesia serta upaya pemerintah dalam mengatasi potensi risiko kehilangan pajak akibat penggunaan e-Commerce serta keterkaitan suatu bisnis yang berkembang pesat yang akan memberikan kontribusi dalam peningkatan perekonomian jika tidak diimbangi dengan peraturan yang berlaku khusus, akan berdampak kurang baik terhadap bidang lain yang juga merupakans sektor utama dalam perwujudan pembangunan, yaitu pajak. Sebelumnya sudah ada penelitian yang dianggap berhubungan dengan penelitian ini di antaranya: Satu, Menguak Permasalahan Perpajakan E-Commerce (Pangesti, 2017), dimana hasilpenelitiannya menyebutkan persamaan penetapan pajak tranasaksi e-Commerce dengan transaksi konvensional dengan dasar hukum pengenaan pajaknya. Perbedaan dengan penelitian ini, penulis di samping meneliti mengenai landasan hukum yang menjadi acuan pelaksanaan pajak, juga meneliti aspek penyebab dari tidak maksimalnya penarikan pajak di Indonesia yang ternyata dipengaruhi oleh banyak faktor. Sementara persamaannya, kedua penelitian memuat aspek kesetaran peraturan perpajakan bagi transaksi e-Commerce maupun konvensional. Kedua, Pemenuhan Kewajiban Perpajakan Bagi Pelaku E-Commerce di Indonesia (Sakti, 2014), menuliskan tentang kesetaraan pajak untuk transaksi e-Commerce dengan transaksi konvensional. Perbedaan dengan penelitian ini, penulis lebih menekankan kepada potensi hilangnya penerimaan pajak dengan adanya kesetaraan pemberlakuan pajak antara e-Commerce dan konvensional, sementara persamaannya sama-sama fokus pada kewajiban pelaku bisnis terhadap pajak. Ketiga, Potensi Perpajakan Terhadap Transaksie-CommercediIndonesia(Valentino \& Wairocana, 2018), persamaannya yaitu membahas mengenai minimnya aturan hukum mengenai perpajakan di Indonesia, sedangkan perbedaannya dengan penulis yaitu didalam penelitiannya tidak menyinggung mengenai studi komparasi ditiap negara maju mengenai suksesnya implementasi pajak e-Commerce, sedangkan dipenelitian ini terdapat studi komparasi mengenai sistem pengenaan pajak di negara-negara maju.

Dalam penelitian ini, dapat dilihat mengenai regulasi dari sisi hukum yang mendasari pengenaan pajak transaksi online beserta risiko-risiko yang timbul pada pelaksanaanya dan sejauh mana pentingnya pengaturan secara khusus dengan mempertimbangkan terbitnya regulasi baru sebagai dasar pengenaan pajak serta caracara yang efektif agar penarikan pajak e-Commerce dapat dilakukan dengan maksimal seperti halnya terhadap transaksi konvensional. Penulis juga menyertakan masukan berupa penguatan sistem monitoring pajak e-Commerce yang dapat dipertimbangkan oleh pemerintah.

\section{METODE}

Metode penelitian yang digunakan adalah penelitian hukum dengan jenis penelitian hukum yuridis normative yaitu pendekatan kepustakaan yang berpedoman pada peraturan-peraturan, buku-buku atau literatur-literatur hukum serta bahan-bahan yang mempunyai hubungan permasalahan dan pembahasan dalam penulisan artikel ini (Hanitijo, 2001). Penelitian menggunakan 
pendekatan dengan menelaah semua peraturan perundang-undangan yang ada hubungannya dengan permasalahan yang sedang dihadapi (statue approach) serta pendekatan analisa konsep hukum (Analytical conseptual approach) yaitu berdasarkan doktrin-dontrin yang berkembang di dalam ilmu hukum.

Bahan hukum yang digunakan yaitu bahan hukum primer yang mencakup peraturan perundang-undangan yang berkaitan dengan perpajakan dan e-Commerce. Bahan hukum sekunder yaitu berupa buku-buku hukum, jurnal-artikel hukum, tesis, pendapat para sarjana serta dokumen yang dengan tema perpajakan dalam e-Commerce. Dan Bahan tersier berupa berita dari internet yang sumbernya dapat dipertanggungjawabkan.

Pengumpulan bahan hukum dilakukan dengan cara melakukan studi dokumen untuk mendapatkan gambaran secara umum mengenai hal-hal yang berhubungan dengan permasalahan yang diteliti serta memperoleh data lainnya yang relevan dengan bidang kajian. Untuk selanjutnya data yang diperoleh dari penelitian kepustakaan selanjutnya dianalisis dan dijabarkan secara kualitatif. Bahan hukum yang terkumpul kemudian dikelompokkan dan dipilah-pilah dicari yang relevan dan representatif yang berhubungan dengannpokok permasalahan. Bahan hukum tersebut selanjutnya dipelajari secara mendalam, ditelaah, dan dipaparkan secara deskriptif, kemudian dibuat kesimpulan yang diharapkan dapat menjawab permasalahan yang diangkat dan dibahas tersebut. Dari sumber hukum yang telah diolah selanjutnya diuraikan dalam bentuk deskriptif kualitatif yang menjelaskan permasalahan serta solusi secara jelas berdasarkan sumber hukum yang. Adapun tahapan-tahapannya meliputi perumusan dasar-dasar hukum, merumuskan pengertian hukum, perumusan kaidah-kaidah hukum dan analisa hukum (Amiruddin dan Asikin, 2004).
Teknik analisis bahan hukum penelitian ini menggunakan penalaran deduktif yaitu cara berpikir dengan menjabarkan sesuatu yang umum dan selanjutnya dikaitkan dengan aspek-aspek khusus (Marzuki, 2011). Penjabaran dari bahan hukum yang diolah selanjutnya dipaparkan secara diskriptif. kemudian dibuat kesimpulan yang diharapkan dapat menjawab permasalahan yang diangkat dan dibahas tersebut mengenai perpajakan dalam e-Commerce.

\section{HASIL DAN PEMBAHASAN \\ Transaksi e-Commerce dan regulasi khusus terkait pajak negara}

Berdagang secara elektronik dengan transaksi bisnis yang terdata secara digital yang dilakukan oleh konsumen dan dari perusahaanmerupakandefinisie-Commerce dari Laudon \& Laudon (1998). Berdasarkan pengertian tersebut, terdapat tiga bagian utama dalam e-Commerce yaitu pertama, adanya proses penjualan dan pembelian yang dilakukan secara elektronik. Kedua, adanya pihak pembeli atau perusahaan. Ketiga, koneksi antar perangkat secara daring untuk melakukan kegiatan bisnis (Laudon \& Laudon, 1998). Sementara itu perdagangan elektronik menurut Surat Edaran Direktorat Jenderal Pajak yaitu SE-62/PJ/2013 adalah aktivitas yang memanfaatkan jaringan komputer untuk melakukan penyebarluasan, pengadaan, marketing produk (barang dan jasa). Arti e-Commerce juga bisa didefinisikan sebagai aktivitas yang dilakukan dengan menggunakan elektronik yang terhubung dengan internet untuk mengadakan transaksi jual beli barang, servis, atau transmisi dana (Pangesti, 2017).

Bertransaksi secara efisien dan efektif dengan sarana internet sangat menarik bagi pedagang, distributor, produsen dan konsumen akhir sebagai pelaku bisnis. Melalui internet, masyarakat memiliki 
ruang gerak yang lebih luas dalam memilih produk (barang dan jasa) yang akan dipergunakan tentunya dengan berbagai kualitas dan kuantitas sesuaii dengan yang diinginkan (Hana, 2018). Kemudian proses transaksi yang dilakukan di penjualan online tergolong sederhana. Didukung dengan biaya operasional yang dikeluarkan lebih rendah dari pedagang konvensional pada umumnya serta meraup omzet yang lebih besar dari omzet yang dihasilkan oleh pedagang konvensional mengakibatkan perlunya pengadaan pemenuhan kewajiban perpajakan.(Sari, 2018).

Lebih lanjut, menurut India Chartered Accounting (2012) terdapat 5 (lima) klasifikasi e-Commerce yaitu: (1) E-Commerce Businness to Business), merupakan transaksi e-Commerce yang dilakukan oleh dua belah pihak yang mengerti dan mengetahui bisnis yang dijalankan dan sama-sama memiliki kepentingan; (2) E-Commerce Business to Consumer, merupakan transaksi e-Commerce antara penyedia dan konsumen, dimana konsumen mendapatkan penawaran produk dan melakukan pembelian melalui daring; (3) E-Commerce Consumer to Consumer, merupakan jual beli yang terjadi antara konsumen ke konsumen, seperti Tokopedia, Bukalapak, OLX dan sejenisnya. Transaksi e-Commerce ini dilakukan secara online melalui market place. Jadi $\mathrm{C} 2 \mathrm{C}$ di sini menjadi perantara antara penjual dan pembeli; dan (4) E-Commerce Consumen to Business, yakni transaksi dimana konsumen bertindak sebagai penjual dan perusahaan bertindak sebagai pembeli (Pangesti, 2017).

Ekonomi digital di Indonesia telah memberikan peran yang besar terhadap pertumbuhan ekonomi negara. Setiap 5 tahunnya diperkirakan akan ada 50 juta pengguna internet baru. Menurut data dari Mc Kinsey, sektor e-Commerce Indonesia untuk formal e-talling seperti Bukalapak, JD, Shoppe dan sejenisnya telah menghasilkan 5 miliar dolar lebih
(Nurfadila, 2018). Sementara untuk Tokopedia sendiri nilai transaksi mencapai satuan triliun rupiah setiap bulan (Agung, 2017). Secara keseluruhan, untuk fornal e-talling diperkirakan akan mencapai US\$ 65 miliar atau sekitar Rp 910 triliun pada 2022 sesuai proyeksi dari Mc Kinsey (Nurfadila, 2018). Data terbaru menyebutkan, di Indonesia penjual online meningkat dua kali lipat setiap tahun dalam kurun waktu tiga tahun terakhir dan mencapai jumlah 4,5 juta aktif (Wahyudi, 2019). Pertumbuhan perdagangan melalui transaksi online berdasarkan data Bank Indonesia, pada Januari 2019, transaksi online mencapai Rp. $8,204 \mathrm{~T}$, mengalami peningkatan sebesar 135,8\% dibandingkan tahun 2018 (Daniel, 2019). Nilai transaksi online sendiri pada tahun-tahun sebelumnya mencapai $200 \mathrm{~T}$ per tahun dengan potensi pendapatan pajak PPN dan PPH 10-15 T per tahun. Namun demikian. banyak ditemui bahwa pelaku bisnis yang memanfaatkan peluang secara online tidak membayar pajak atau memang tidak mengenakan pajak pada produk yang dijualnya terutama pelaku bisnis dalam skala kecil.

Pendapatan pajak dari transaksi e-Commerce yang belum maksimal, disamping karena banyak pelaku e-Commerce yang belum menunaikan kewajiban pajaknya, juga karena faktor sampai dengan saat ini peraturan pajak secara khusus bagi transaksi e-Commerce masih belum ada. Pajak untuk e-Commerce diberlakukan sama dengan pajak konvensional sebagaimana ketentuan yang ada di dalam Peraturan Menteri Keuangan Nomor 210/PMK.010/ 2018 tentang perlakuan perpajakan atas transaksi perdagangan melalui sistem elektronik. Dipastikan bahwa regulasi perpajakan tersebut untuk menerapkan perlakuan yang setara antara pelaku usaha konvensional dan e-Commerce. Peraturan tersebut tidak memuat penetapan jenis tarif bagi pelaku perdagangan secara daring. Peraturan hanya mengenai sistem perpajakan dengan 
memudahkan administrasi dan mendorong kepatuhan perpajakan e-Commercer yang diberlakukan setara dengan pelaku usaha konvensional sehingga dapat menciptakan keadilan dalam pengenaan pajak (Kemenkeu, 2019).

Adapun dasar hukum Pengenaan PPN atas transaksi e-Commerce tertera dalammUU PPN Pasal 1, Pasal 4 ayat (1) huruf $\mathrm{c}$ dan huruf e, pasal 11 ayat (1) dan (2), dan pasal 13. Selain diatur dalam UU PPN, dasar hukum atas pajak e-Commerce ini juga terdapat dalam Peraturan Pemerintah Nomor 1 Tahun 2012 Pasal 6, Pasal 10, Pasal 11, dan Pasal 17 ayat (1,5,6 dan 7). Di samping itu, e-Commerce wajib dikenakan Pajak Penghasilan (PPh). Sebagaimana disampaikan (Makalalag, 2016), transaksi perdagangan secara online memiliki potensi untuk dapat dikenakan pajak penghasilan, meskipun secara khusus belum ada aturan yang mengatur perlakuan $\mathrm{PPh}$ atas pengusaha perdagangan online. Dalam hal ini wajib untuk dilakukan pemungutan $\mathrm{PPh}$, pemotongan $\mathrm{PPh}$ jika penghasilan dari penjualan barang atau penyediaan jasa merupakan objek PPh. Yang mendasari diberlakukannya $\mathrm{PPh}$ atas transaksi e-Commerce adalah UU $\mathrm{PPh}$ Pasal 14 ayat (1) dan ayat (2), Pasal 15, Pasal 17, Pasal 21, Pasal 22, Pasal 23, dan Pasal 26.

Selainitupemerintahjugamenerbitkan satu ketentuan yang dituangkan dalam Paket Kebijakan Ekonomi Jilid XIV pada 10 November 2016 dimana pemerintah memberikan insentif kepada pelaku start up e-Commerce untuk mendapat keringanan, yaitu: (1) Bagi dalam negeri yang melakukan investasi pada perusahaan startup, akan mendapatkan pengurangan pajak; (2) Bagi start up e-Commerce yang beromzet di bawah Rp. 4,8 miliar dengan peredaran bruto tertentu per tahun mendapat penyederhanan izin prosedur melalui pelaksanaan Peraturan Pemerintah No. 44 tahun 2013 dengan mendapatkan pajak final sebesar 0,5\%; dan (3) Menetapkan persamaan perilaku pajak seluruh ketentuan perpajakan (Melani, 2019).

Jika diperhatikan, terlihat bahwa peraturan yang diterbitkan oleh pemerintah tersebut hanya berisi keringanan bagi start up e-Commerce, tetapi tidak mengatur hal lain terkait perlakuan pajak bagi e-Commerce secara umum tersendiri.

\section{Upaya Pemerintah Indonesia Dalam Mengatasi Risiko Kehilangan Pajak Akibat Penggunaan Transaksi Online}

Pajak memegang peranan yang sangat penting sebagai salah satu sumber pendapatan negara. Danaayang berasal dari pajak dipergunakan bagi penyelenggaraan dan aktivitas pemerintahan (Melisa, 2016). Pajak pada hakikatnya mengenai hidup negara secaraa ekonomis, demikian pula pajak merupakan sumber pendapatan utama negara di samping sumber alam (natural resources) (Juhaeni, 2011) dan merupakan penyumbang sumber penerimaan terbesar dalam komposisi penerimaan negara. Oleh karena itu, pajak menjadi komponen penting agar pemerintahan tetap berjalan dengan baik (Kiswara, 2011). Adapun potensi pemasukan pajak dari bisnis online bisa diambil dari: (1) Pajak Pertambahan Nilai (PPN) bagi Pengusaha Kena Pajak dengan total pendapatan kotor sampai Rp. 4,8 miliar per tahun, wajib memungut PPN atas setiap transaksinya. Hal ini berdasarkan ketetapan Pemerintah yang berlaku sejak 1 Januari 2014 dan (2) Pajak Penghasilan $(\mathrm{PPh})$ dengan ketentuan pajak atas penjual melalui online yang tidak melebihi Rp. 4,8-miliar untuk penghasilan/ omzet brutonya, berdasarkan PP Nomor 46 tahun 2013, pajaknya 1\% dari omzet, diperlakukan sama dengan UMKM (Pangesti, 2017).

Sementara itu, melalui SE-06/ PJ/2015 Direktorat Jendral Pajak secara tegas mengeluarkan peraturan terkait pemotongan dan/atau pemungutan PPh bagi 
transaksi e-Commerce dimana ada empat model transaksi e-Commerce yang dapat dikenakan pajak, yaitu; pertama, Online Market place (Penyedia Layanan Jual Beli Online), yaitu kegiatan menyediakan tempat kegiatan usaha berupa toko online di internet yang menjadi pertemuan antara penjual dan pembeli yang sudah masuk dalam daftar sebagai anggota untuk melakukan jual beli secara daring. Kedua, Class field Ads (Jasa Layanan Pasang Iklan di Situs Online), yaitu kegiatan yang memberikan tempat secara online untuk menampilkan produk atau jasa dalam bentuk teks, grafik, video.

Ketiga, Daily Deals, yakni penyediaan tempat kegiatan usaha berupa situs daily deals sebagai tempat merchant menjual barang dan/atau jasa kepada konsumen dengan menggunakan voucher sebagai sarana pembayaran. Keempat, Online Retail, yakni kegiatan penjualan yang dilakukan oleh penyelenggara kepada pembeli di situs mereka (Pangesti, 2017).

Bagi ke empat model transaksi tersebut, pada umumnya pemotongan pajak dilakukan pada pembayaran imbalan jasa penyediaan tempat dan/waktu dalam media massa, media luar ruang atau media lain untuk penyampaian informasi; imbalan bagi perantara; pembayaran atau fee transaksi; dan jasa lain jika ada keterlibatan pihak lain. Pemungutan/pemotongan pajak ini hanya dapat terlaksana jika pajak dipotong/dipungut oleh pihak yang ditunjuk oleh Direktorat Jenderal Pajak sebagai Pemotong/Pemungut pajak. Sementara untuk kewajiban PPN-nya, sesuai ketentuan umum perpajakan, apabila sampai dengan suatu bulan dalam tahun buku/kalender besarnya pendapatan dari penyerahan barang atau jasa kena pajak yang dilakukan pelaku e-Commerce lebih dari Rp. 4,8 miliar, maka pelaku e-Commerce wajib melakukan pelaporan atas usahanya agar dikukuhkan sebagai pengusaha kena pajak (PKP) dan berkewajiban untuk memungut
PPN atas setiap transaksi penyerahan barang atau jasa kena pajak dengan cara menerbitkan faktur pajak (e-faktur). Selain itu, terdapat kewajiban lainnya yaitu dalam hal pajak keluar lebih besar daripada pajak masukan yang dapat dikreditkan, maka yang bersangkutan wajib menyetorkan PPN yang masih harus dibayar serta menyetorkan Pajak Penjualan (Panjaitan, 2017)

Pada dasarnyaa prinsip perpajakan yang menjadi penilaian untuk regulasi transaksi e-Commerce telah dikemukakan OECD pada tahun 2000 dalam laporan yang dibuatooleh Committee of Fiscal Affairs sebagaimana dikutip Nufransa Wira Sakti dalam E-Commerce as the Tax Potential Revenueein Indonesia, meliputi prinsip: (1) tidak memihak, yaitu ketentuan perpajakan patut bersifat netral untuk model perdagangan secara keseluruhan, baik elektronik maupun tradisional; (2) efisensi, adanya biaya seperti biaya kepatuhan untuk wajib pajak dan biaya administrasi untuk Direktorat Jenderal Pajak harus benarbenar diminimalkan; (3) kepastian dan kesederhanaan, peraturan perpajakan harus jelas dan mudah dipahami sehingga wajib pajak mengetahui pengenaan pajak ketika transaksi dilakukan; (4) efektivitas dan keadilan, perhitungan pajak harus benarbenar tepat pada waktu yang tepat; dan (5) fleksibel, sistem perpajakan harus tidak kaku serta dinamis untuk memastikan bahwa sistem dapat mengikuti perkembangan teknologi dan perdagangan (Sakti, 2017).

Secara prinsip, jual beli barang atau jasa dengan menggunakan e-Commerce pada dasarnya tidak ada perbedaan dengan perdagangan secara konvensional, hanya berbeda cara melakukannya saja. Atas dasar hal tersebut maka pengenaan e-Commerce diberlakukan sama dengan konvensional (Sakti, 2014). Hal tersebut sesuai pula dengan asas dan prinsip perpajakan yaitu "Asas Keadilan" (Sari, 2018). Berbekal dari pernyataan tersebut seharusnya 
pajak atas e-Commerce bisa dilaksanakan tidak berbeda dengan pajak atas transaksi konvensional. Direktorat Jendral Pajak Kementerian Keuangan menyebut banyak pelaku transaksi online yang tidak patuh membayar pajak walaupun sudah memenuhi persyaratan yaitu tercapainya omzet di atas 4,8 M. Salah satu pendukung hal ini karena sistem pelaporan pajakddi Indonesiau menggunakan self assesment, yaitu sistem pemungutan pajak yang memberikan kepercayaan kepada Wajib Pajaki (WP) agar menghitung, menyetor, dan melaporkan sendiri jumlah pajak yang seharusnya terutang berdasarkan peraturan perundang-undangan. Hal ini diketahui dengan data yang menunjukkan dimana transakasi online mencapai Rp. 100 triliun lebih serta terdapat kenaikan selama 5 (lima) tahun terakhir (Devani, 2006).

Permasalahan yang terjadi dalam implementasi pajak berkaitan dengan transaksi e-Commerce sering berhubungan dengan kepribadian mereka yang menjadi pihak di dalam bertransaksi (Bozdoğanoğlu, 2015). Jadi apabila pihak yang terlibat dalam transaksi e-Commerce umumnya mempunyai mempunyai kepribadian cenderung tidak patuh terhadap kewajiban membayar pajak, maka secara otomatis pemungutan pajak untuk transaksi e-Commerce akan menghadapi banyak kendala (Lim dan Indrawati, 2016). Sementara itu, pada penerapan peraturan pajak penghasilan dalam Undang-Undang Pajak Penghasilan, permasalahan yang timbul diantaranya adalah belum terdatanya pelaku usaha Online, rendahnya kesadaran pelaku usaha online selaku wajib pajak, pelaku usaha online selaku wajib pajak belum memiliki NPWP (Lubis et al, 2017). Pada akhinya berujung dalam hal pengawasan dan penanganan perpajakan atas transaksi e-Commerce adalah keberadaan sistem Internal dari DJP yang belum mampu memberikan kebutuhan data yang tepat untuk para pelaku usaha online dan peredaran transaksi yang terjadi (Aprilia, 2014).

Pelaku usaha online selaku wajib pajak seharusnya diwajibkan untuk memiliki Nomor Pokok Wajib Pajak (NPWP) sebagai sarana dalam administrasi perpajakan, yang berguna sebagai tanda pengenal diri atau identitas wajib pajak dalam melaksanakan hak dan kewajiban perpajakannya yang dicantumkan dalam setiap dokumen perpajakan dan dapat menjaga ketertiban dalam pembayaran pajak dan pengawasan administrasi perpajakan (Lubis \& Rahmaini, 2017). Selain itu, ketidakmampuan pemerintah meraih secara maksimal pajak e-Commerce juga disebabkan antara lain karena (1) Jual beli online terjadi secara cepat yang berakibat sulit untuk melacak siapapelakuusahanya;(2)Yang diperdagangkan kebanyakan bentuk barang atau jasa dengan format digital (non fisik) seperti perangkat lunak; (3) Bukti transaksinya adalah bukti elektronik sehingga membuat transaksi e-Commerce semakin sulit dilacak; (4) Transaksi e-Commerce bisa terjadi di seluruh wilayah di luar batas pabean Indonesia atau suatu negara dan memungkinkan menembus batas geografis (Makalalag, 2016); dan (5) Kekurangan sarana software maupun hardware mumpuni pihak pemerintah Indonesia untuk bisa melakukan pengawasan terhadap transaksi e-Commerce tersebut (Setyowati, 2017)

Permasalahan lain yang mendukung terhambatnya penarikan pajak pada pelaku bisnis e-Commerce yaitu mengenai $\mathrm{PPh}$ terhadap pengusaha e-Commerce yang keberadaan fisiknya tidak ada di Indonesia. Sebagaimana Pasal 2 ayat (5) UU PPh menjelaskan pengertian Bentuk Usaha Tetap terdapat 3 (tiga) hal, yakni adanya keberadaan fisik, terdapat aktivitas usaha yang dilakukan dan adanya agen yang kedudukannya tidak bebas yang bertindak untuk dan atas nama orang pribadi atau badannyang tidak bertempat tinggal atau tidak bertempat kedudukan di Indonesia. 
Saat ini, tidak hanya Indonesia saja yang mengalami pertumbuhan transaksi e-Commerce yang sangat pesat. Di beberapa negara di dunia juga mengalami fenomena tersebut. Namun, beberapa negara tesebut ada kesimbangan antara jumlah perdagangan yang dilakukan secara online dengan pendapatan pajaknya. Beberapa negara yang memiliki mekanisme penarikan pajak atas transaksi e-Commerce sebagai berikut: pertama, Jepang. Negara matahari terbit ini bahkan menyatakan bahwa penerimaan terbesar pajak negaranya berasal dari transaksi e-Commerce. Penerapan pemungutan pajak e-Commerce sudah diterapakan sejak tahun 2002 lalu. Cara yang digunakan oleh Jepang adalah dengan membentuk Profesional Team for e-Commerce Taxation (Protect), sebuah unit khusus pada National Tax Agency (NTA) yang bertugas mendeteksi transaksi e-Commerce. Unit tersebut terintegrasi di otoritas perpajakan. Tingginya pelaku industri ini juga tingkat fluktuatif serta perdagangan lintas negara dimana transaksi dilakukan di dunia maya, membutuhkan kepiawaian di bidang teknologi informasi agar memperoleh data dari pelaku bisnis dan jenis barang atau jasa yang ditransaksikan. Sasaran dari team khusus tersebut juga seluruh lapisan, tidak hanya perusahaanperusahaan besar saja melainkan juga ibu-ibu rumah tangga yang memiliki bisnis jualan online. Dengan tarif pajak 8\% tiap transaksi, Protect menghimpun lebih dari $35 \%$ penerimaan pajak Jepang secara keseluruhan.

Kedua, Republik Korea, Singapura, Malaysia, RRC, dan Thailand. Negaranegara ini menggunakan cara yang sama dalam menarik pajak transaksi e-Commerce. Negara-negara tersebut menerapkan sistem National Payment Gateway (NPG), sehingga pemungutan pajaknya dapat lebih efektifdan efisien. Dengan NPG, pungutan PPN lebih mudah sebab seluruh bank yang melayani transaksii online atau jasa pembayaran lain terhubung dengan lembaga switching NPG. Khusus untuk Singapura, terdapat $e$-NETS yang merupakan lembaga domestic switching yang bertugas merekammsemua transaksi online yang terjadi di Singapura. E-NETS menjadi lembaga switching NPG bagi semua kartu kredit (JCB, American Express, Master Card atau Visa) yang menggunakan mata uang lokal dolar Singapura, e-NETS juga sebagai lembaga switching untuk Internet Banking semua bank konvensional di Singapura (Latief, 2017).

Dengan adanya contoh-contoh keberhasilan negara lain atas penerapan pajak transaksi e-Commerce, pemerintah diharapkan untuk secepatnya membuat dan memtuskan mekanisme dan regulasi yang tepat guna pelaksanaan penerapan pajak e-Commerce. Karena sangat disayangkan sekali jika tidak segera diambil tindakan mengingat potensi pajak yang besar dari transaksi e-Commerce yang bisa dihimpun oleh pemerintah. Sebagaimana disampaikan oleh ekonom senior Indonesia, Aviliani, bahwa PPh dan PPN masih tepat dikenakan pada transaski e-Commerce karena menurut regulasi pajak, segala sesuatu yang merupakan penerimaan wajib dikenakan pajak(Latief, 2017). Untuk itu, saat ini terlihat Pemerintah sedang mengupayakan agar penerapan pajak atas transaksi e-Commerce dapat dilakukan secara maksimal dengan melakukan beberapa upaya, di antaranya dimana kementrian perdagangan sedang mempersiapkan Rancangan UndangUndang (RUU) tentang pengaturan pajak perdagangan online, disiapkannya aturan yang merupakan turunan oleh Kementrian Komunikasi dan Informasi tentang tata cara jual beli secara elektronik serta Ditjen Pajak akan bekerjasama dengan lembaga Teknologi Informasi dan Perbankan untuk mendeteksi perdagangan online yang susah dilacak.

Pondasi agar pengenaan Pajak Penghasilan dan Pajak Pertambahan Nilai 
tepat sasaran adalah ketersediaan data transaksi keuangan yang jelas, baik dari perorangan maupun perusahaan. Jadi pada dasarnya terletak pada payment gateway yang akan memudahkan penarikan pajak sebagaimana disampaikan oleh Direktur Eksekutif Center for Indonesia Taxation Analys (CITA) Yustinus Pranowo (Latief, 2017). Payment Gateway adalah sistem yang dapat dipertimbangkan pemerintah untuk diterapkan di Indonesia. Saat ini, yang terbaru adalah Bank Indonesia (BI) sedang mengusahakan sistem NPG dengan menerbitkan Peraturan Bank Indonesia Nomor 19 Tahun 2017 tentang Gerbang Pembayaran Nasional (National Payment Gateway), yang dipersiapkan sebagai kerangka kerja perwujudan NPG. Di Indonesia saat ini ada 3 (tiga) operator pembayaran yakni Artajasa dikenal sebagai pengelola ATM Bersama, Rintis Sejahtera yang merupakan pengelola Prima, dan Daya Network Lestari yang menjadi pengelola ALTO. Kemungkinan besar Bank Indonesia akan menunjuk salah satu operator tersebut untuk bertindak sebagai pengelola tunggal NPG. Atau bisa juga Bank Indonesia akan menerapkan peraturan implementasi yang benar-benar berbeda model dari Singapura (Latief, 2017).

\section{SIMPULAN}

Dari penelitan yang dilakukan menujukkan selain regulasi yang kuat juga dibutuhkan pengawasan dan sisem yang mumpuni agar implementasi pajak transaksi online bisa maksimal. Hal ini diperlukan untuk mengimbangi tingkat kesadaran masyarakat dalam ketaatan membayar pajak khususnya pada transaksi onlne yang masih kurang. Selain dibutuhkan soialisasi secara terus menerus, diharapkan pemerintah dapat mempercepat proses pelaksanaan payment gateway. Dengan payment gateway, maka lalu lintas perdagangan secaa online bisa dimonitor dan pemerintah akan memilki data asli dari pergerakan transaksi onlne sehigga bisa diketahui secara pasti potensi pajak yang bisa diraih, pajak yang sudah bisa diraih dan pajak yang belum masuk. Dengan demikian maka potensi kehilangan pajak negara karena transaksi online bisa dihindari dengan adanya pengaturan pajak transaksi e-Commerce secara tepat berikut implementasi yang efisien serta sanksi yang tegas atas pelanggaran-pelanggarannya.

\section{DAFTAR PUSTAKA}

Undang-Undang Nomor 7 Tahun 1983 tentang Pajak Penghasilan

Surat Edaran Direktorat Jenderal Pajak Nomor SE-62/PJ/2013 tentang Penegasan Ketentuan Perpajakan Atas Transaksi E-Commerce

Peraturan Menteri Keuangan Nomor 210/ PMK.010/2018 tentang perlakuan perpajakan atas transaksi perdagangan melalui sistem elektronik

Peraturan Pemerintah No. 44 tahun 2013 tentang pajak penghasilan dari usaha yang diterima atau diperoleh wajib pajak yang memiliki peredaran bruto tertentu

Surat Edaran nomor SE-06/PJ/2015 Direktorat Jenderal tentang Pemotongan Dan/ Atau Pemungutan Pajak Penghasilan AtassTransaksi E-Commerce

Peraturan Bank Indonesia Nomor 19 Tahun 2017 tentang Gerbang Pembayaran Nasional (National Payement Gateway)

Agung, Bintoro. (2017). Transaksi di Tokopedia Capai Triliunan Rupiah Tiap Bulan, diakses (Online) melalui (https://www.cnnindonesia.com/ teknologi/ 20171129101240-185258834/transaksi-di-tokopedia-capaitriliunan-rupiah-tiap-bulan?) diakses tanggal 22 Oktober 2020

Amiruddin \& Asikin, Zainal. (2004), Pengantar Metodologi Penelitian Hukum. Jakata: Raja Grafindo Persada 
Aprilia, A. (2014). Penanganan Dan PengawasanPerpajakan DalamRangka Intensifikasi Di Bidang E-Commerce (Studi Pada Kantor Pelayanan Pajak Pratama Malang Selatan). Jurnal Mahasiswa Perpajakan, 2 (1), 1-10

Bozdoğanoğlu,Burçin.(2015).E-Commerce Taxation in National and International Area, International Journal of Humanities and Management Science (IJHMS), Vol. 3, Issue 3

Decky. (2019). E-Commerce Di Era Industri 4.0 Dan Society 5.0, Jurnal Ilmiah Ekonomi Kita (IQTISHADUNA), Vol. 8 (2), 171-184

Devani, S. (2006). Perpajakan: Konsep, Teori, dan Isu. Jakarta: Kencana

Farras, Bernhart. (2019). Kritik Keras Pengusaha Atas Aturan Pajak e-Commerce. Diakses (Online) melalui (https://www.cnbcindonesia. com/tech/20190114142544-3750544/kritik-keras-pengusaha-atasaturan-pajak-e-Commerce) diakses tanggal 04 November 2020

Hana. (2018). Kajian Hukum Kewajiban Pajak Terhadap Perdagangan Online di Internet. Jurnal Hukum Universitas Sumatra Utara, diakses (Online) melalui (https://jurnal.usu.ac.id/index.php/ transparency/article/view/23419/10306) diakses tanggal 04 November 2020

Hanitijo, R. (2001). Metetologi Penelitian Hukum dan Jurimetri. Jakarta: Ghalia Indonesia

Hendarsyarh, Decky. (2019). E-Commerce Di Era Industri 4.0 Dan Society 5.0. Jurnal Ilmiah Ekonomi Kita (IQTISHADUNA), Vol. 8 (2), 171-184

Juhaeni,D.Y.(2011). "PengaturanPemungutan dan Pengawasan Pajak Pada Transaksi Melalui Elektronic Commerce (E-Commerce) Guna Meningkatkan Penerimaan Negara", Tesis Magister Kenotariatan Pascasarjana Universitas Padjadjaran, Bandung
Laudon, Kenneth C. \& Laudon. Jane.P.(1998). Management Information System-New Approaches to Organize \& Technology. New Jersey: Prentice Hall

Latief, Muhammad. (2017). Belajar Soal Memajaki Transaksi e-Commerce dari Tetangga, diakses (Online) melalui (https://www.aa.com.tr/id/ analisis-berita/belajar-soal-memajakitransaksi-e-Commerce-daritetangga/941706) diakses tanggal 04 November 2020

Leonardo, Christine T. (2020). Penerapan Ketentuan Perpajakan pada Transaksi E-Commerce pada Platform Market place, Jurnal Pendidikan Akuntansi Dan Keuangan, Vol. 8, No. 1, 45-54

Lim, Setiadi dan Indrawati, Lilik. (2016). Perlakuan Pajak Pertambahan Nilai Transaks E-Commerce di Indonesia. Jurnal Bisnis Perspektif, Vol. 8, No. 1, 36-57

Lubis, Melisa Rahmaini. (2017). Kebijakan Pengaturan Pajak Penghasilan dan Pajak Pertambahan Nilai Terhadap Transaksi E-Commerce, Jurnal Ilmiah Hukum Administrasi Negara Fakultas Hukum Universitas Lampung, Vol. 4, No. 1, 1-15

Makalalag, Leonard. (2016). Pengenaan Pajak Penghasilan Terhadap Pengusaha Dalam Transaksi Perdagangan Online (E-Commerce), Jurnal Ilmu Hukum Legal Opinion, Edisi 1, Vol. 4, 1-10

Melani, Agustina. (2019). Pajak e-Commerce Efektif Berlaku 1 April 2019, diakses (Online) melalui (https://www. liputan6.com/bisnis/read/3870030/ pajak-e-Commerce-efektif-berlaku-1april-2019) diakses tanggal 22 Oktober 2020

Lubis, M. R.; Nurmayani; \& Putri, Marlia Eka. (2017). Kebijakan Pengaturan Pajak Penghasilan dan Pajak Pertambahan Nilai Terhadap Transaksi E-Commerce', Jurnal Ilmiah Hukum 
Administrasi Negara Fakultas Hukum Universitas Lampung, Vol. 4 No. 1, 1-15

Nurfadila. (2018). McKinsey: Tahun 2022, Pasar E-Commerce Indonesia Capai Rp 955 Triliun, diakses (Online) melalui (https://ekonomi.kompas. $\mathrm{com} / \mathrm{read} / 2018 / 09 / 03 / 093900726$ / mckinsey--tahun-2022-pasar-eCommerce-indonesia-capai-rp-955triliun) diakses tanggal 23 Oktober 2020

Pangesti,R.D.(2017).MenguakPermasalahan Perpajakan e-Commerce, Jurnal Riset Akuntansi dan Bisnis Airlangga, Vol 2 (1), 181-201

Panjaitan, Sejar. (2017). Perlakuan Pajak atas Transksi E-Commerce, Majalah Pajak, diakses (Online) melalui (https://majalahpajak.net/perlakuanpajak-atas-transaksi-e-Commerce/) diakses tanggal 22 Oktober 2020

Rahayu, Ning. (2019). Pertumbuhan e-Commerce Pesat di Indonesia, diakses (online) melalui (https:// www.wartaekonomi.co.id/ read 216302 /pertumbuhan-eCommerce-pesat-di-indonesia.html) diakes tanggal 26 Oktober 2020

Sakti, N. W. (2017). E-Commerce as The Tax Potential Revernue in Indonesia. Nigata University Graduate School of Modern Society Arts and Sciences: Contemporary Social and Cultural Studies, 240

Sakti, N. W. (2014). Pemenuhan Kewajiban Perpajakan Bagi Pelaku e-Commerce Di Indonesia dalam Seminar Perpajakan yang diadakan oleh Direkorat Jenderal (Ditjen) Pajak di Jakarta, 27 Agustus. Makalah

Sari, R. P. (2018). Kebijakan Perpajakan atas transaksi e-Commerce, Akuntabel: Jurnal Akuntasi dan Keuangan, 67-71.

Sari. (2018). Analisis Terhadap Penerapan Pajak Atas Transaksi E-Commerce. Yogyakarta: Universitas Islam Indonesia
Soekanto, Soerjono. (1986). Pengantar Penelitian Hukum. Jakarta: UI Press Valentino, Finanto \& Wairocana, I Gusti Ngurah. (2018). Potensi Perpajakan Terhadap Transaksi E-Commerce di Indonesia. Jurnal Ilmu Hukum Kertha Negara, Vol. 7 (1), 1-15

Vidyana, Adhysty \& Amachi, Tubagus C. (2014). Studi Terhadap Kelemahan Pendeteksian Transaksi Dunia Maya (E-Commerce) Di Indonesia, Artikel FE Universitas Indonesia, diakses (online) melalui (www.lib.ui.ac.id/ naskahringkas/2016-05/S57290Adhysty\%20Vidyana) diakses tanggal 04 November 2020

Zuraya, Nidia. (2019). Pertumbuhan E-Commerce Indonesia Tertinggi di Dunia. Republika Online, 27 Februari 2019. Diakses (Online) melalui (https://www.republika.co.id/berita/ ekonomi/korporasi/pnkrfg383/ pertumbuhan-emecommerceemindonesia-tertinggi-di-dunia), tanggal 26 Oktober 2019 